\title{
Detection of integrated high risk human papillomavirus in adenoid cystic carcinoma of the uterine cervix
}

W Grayson, L Taylor, K Cooper

\begin{abstract}
Aim-To investigate the role of human papillomavirus (HPV) in adenoid cystic carcinoma of the uterine cervix.

Methods-Eleven archival, paraffin wax embedded specimens were analysed by non-isotopic in situ hybridisation (NISH) for HPV types 6, 11, 16, 18, 31, and 33 using digoxigenin labelled probes. The polymerase chain reaction (PCR) was carried out on each of the cases using consensus primers to HPV.

Results-A total of eight adenoid cystic carcinomas harboured the HPV genome by NISH, of which five were PCR positive. Integrated HPV 16 DNA was demonstrated in seven of the eight NISH positive cases. One adenoid cystic carcinoma showed integrated HPV 31. HPV DNA was not detected in the three remaining cases. Conclusions-Integrated high risk HPV genome, in particular type 16, is associated with this uncommon type of primary cervical cancer.

( Clin Pathol 1996;49:805-809)
\end{abstract}

Keywords: adenoid cystic carcinoma, cervix, human papillomavirus.

Adenoid cystic carcinoma of the cervix is a rare neoplasm originally described by McGee $e t$ al in 1965..$^{1}$ Although adenoid cystic carcinoma is classically described in salivary glands, ${ }^{2}$ similar tumours may arise in the bronchus, ${ }^{3}$ oesophagus, ${ }^{4}$ breast,${ }^{5}$ sinonasopharyngeal region, ${ }^{6}$ ear, ${ }^{7}$ and prostate. ${ }^{8}$

The association between human papillomavirus (HPV) and the evolution of squamous epithelial neoplasms of the genital tract is well documented. ${ }^{9}{ }^{10}$ To date, over 70 different HPV types have been identified. ${ }^{10}$ Certain types, such as HPV 6 and 11, are regarded as low risk as these types are associated predominantly with genital condylomata and low grade cervical dysplasia. Other types, such as 16 and 18 and to a lesser extent $31,33,35,45,51,52$, and 56 , however, are regarded as high risk viruses because of their well recognised association with high grade cervical intraepithelial neoplasia and invasive carcinoma. ${ }^{11}$

Integration of high risk HPV DNA into the human genome is a crucial step in the evolution of HPV induced cervical cancers. ${ }^{12}{ }^{13}$ Non-isotopic in situ hybridisation (NISH) has emerged as an invaluable technique in the identification of both episomal and integrated HPV in archival cervical biopsy material. ${ }^{14-17}$
Several previous studies have focused on the role of HPV integration in cervical intraepithelial neoplasia (CIN),$^{15}$ invasive squamous carcinoma, ${ }^{13}{ }^{16}{ }^{18}$ cervical adenocarcinoma, ${ }^{17-20}$ adenosquamous carcinoma, ${ }^{19}$ and small cell carcinoma. ${ }^{18}$

The present study investigated the role of HPV integration in adenoid cystic carcinoma, a distinctly uncommon primary cervical neoplasm representing less than $1 \%$ of cervical adenocarcinomas. ${ }^{21}$

\section{Methods}

Eleven formalin fixed, paraffin wax embedded specimens of adenoid cystic carcinoma, taken between 1974 and 1995, were obtained from the archival surgical files of our department. The specimens comprised 10 cervical biopsy and one hysterectomy specimen. Parallel haematoxylin and eosin slides of the adenoid cystic carcinoma were reviewed and classified using established morphological criteria. ${ }^{22-25}$

NON-ISOTOPIC IN SITU HYBRIDISATION

Non-isotopic in situ hybridisation was performed as described previously. ${ }^{15}$ Sections, $4 \mu \mathrm{m}$ thick, from the paraffin wax embedded tissue samples were cut and placed on slides pretreated with aminopropyltriethoxysilane (Sigma, St Louis, Missouri, USA). The sections were allowed to dry overnight at $42^{\circ} \mathrm{C}$ and then dewaxed and rehydrated according to standard protocols. The slides were treated with $3 \%$ hydrogen peroxide in methanol to reduce residual non-specific peroxidase activity. Unmasking of nucleic acids was achieved by a limited proteolysis in proteinase $\mathrm{K}(500 \mu \mathrm{g} / \mathrm{ml})$ at $37^{\circ} \mathrm{C}$. This reaction was stopped in distilled water after 15 minutes and the slides were air dried. Aliquots of hybridisation mix $(6 \mu \mathrm{l})$ containing $2 \mathrm{ng} / \mu \mathrm{l}$ digoxigenin labelled HPV 6, 11 , $16,18,31$, or 33 (gift from Professor JO'D McGee, Oxford, UK) were added to each well on multispot slides, which were covered with a $14 \mathrm{~mm}$ glass coverslip. The slides were then placed in a moist Terasaki plate. Target DNA and probe were denatured in a hot air oven at $95^{\circ} \mathrm{C}$ for 15 minutes and then allowed to hybridise at $42^{\circ} \mathrm{C}$ for two hours. The sections were then subjected to two post-hybridisation washes of five minutes each in $4 \times$ SSC (standard saline citrate) buffer and incubated in TBT (Tris buffered saline containing 5\% (w/v) bovine serum albumin and $5 \%(\mathrm{v} / \mathrm{v})$ Triton $\mathrm{X}-100$ ) for 10 minutes.

Detection of hybridised probe followed conventional immunohistochemical techniques.

Department of Anatomica

PO Box 1038, Johannesburg 2000, South Africa. 
Table 1 PCR primer sequences for the HPV E6 and $\beta$-globin ${ }^{26}$ genes

\begin{tabular}{llll}
\hline Primer & ${\text { 5' } \rightarrow 3^{\prime} \text { Nucleotide sequence }}^{\star}$ & Target & Strand \\
\hline WD72 & CGGTCGGGACCGAAAACGG & HPV E6 & Positive \\
WD76 & CGGTTSAACCGAAAMCGG & HPV E6 & Positive \\
WD66 & AGCATGCGGTATACTGTCTC & HPV E6 & Negative \\
WD67 & WGCAWATGGAWWGCYGTCTC & HPV E6 & Negative \\
WD154 & TCCGTGTGGTGTGTCGTCC & HPV E6 & Negative \\
GH20 $\dagger$ & GAAGAGCCAAGGACAGGTAC & $\beta$-globin & Positive \\
PCO4 & CAACTTCATCCACGTTCACC & $\beta$-globin & Negative \\
\hline
\end{tabular}

^Degenerate code: $W=A+T ; Y=C+T ; S=G+C$.

†Product size $268 \mathrm{bp}$.

Table 2 Clinical profile of 11 cases of adenoid cystic carcinoma of the cervix

\begin{tabular}{llll}
\hline Case number & Age (years) & Race & Specimen \\
\hline 1 & - & - & Hysterectomy \\
2 & - & - & Biopsy \\
3 & - & Black & Biopsy \\
4 & 68 & Black & Biopsy \\
5 & 67 & Black & Biopsy \\
6 & 109 & Black & Biopsy \\
7 & 77 & Black & Biopsy \\
8 & - & Black & Biopsy \\
9 & 54 & Black & Biopsy \\
10 & 93 & Black & Biopsy \\
11 & 74 & Black & Biopsy \\
\hline
\end{tabular}

$-=$ data not available.

Sections were incubated for 30 minutes with monoclonal anti-digoxigenin ( 1 in 10 000; Sigma) followed by biotinylated rabbit antimouse $F\left(a b^{\prime}\right) 2$ fragment ( 1 in 200; Dako, Glostrup, Denmark) for 30 minutes. Final incubation was in avidin-peroxidase conjugate ( 1 in 75 ; Dako) containing non-fat dry milk $(0.05 \mathrm{mg} / \mu \mathrm{l})$ as a further means of reducing non-specific nuclear staining. All dilutions of anti-sera were made up in TBT. Sections were incubated in diaminobenzidine as chromogen substrate and counterstained lightly in Mayer's haematoxylin. Positive controls obtained from tissues known to contain specific HPV types were included in each run.

POLYMERASE CHAIN REACTION

Two $10 \mu \mathrm{m}$ sections of tissue were cut from each specimen and placed on a clean glass slide. The proper PCR protocol was observed at all times to prevent contamination and

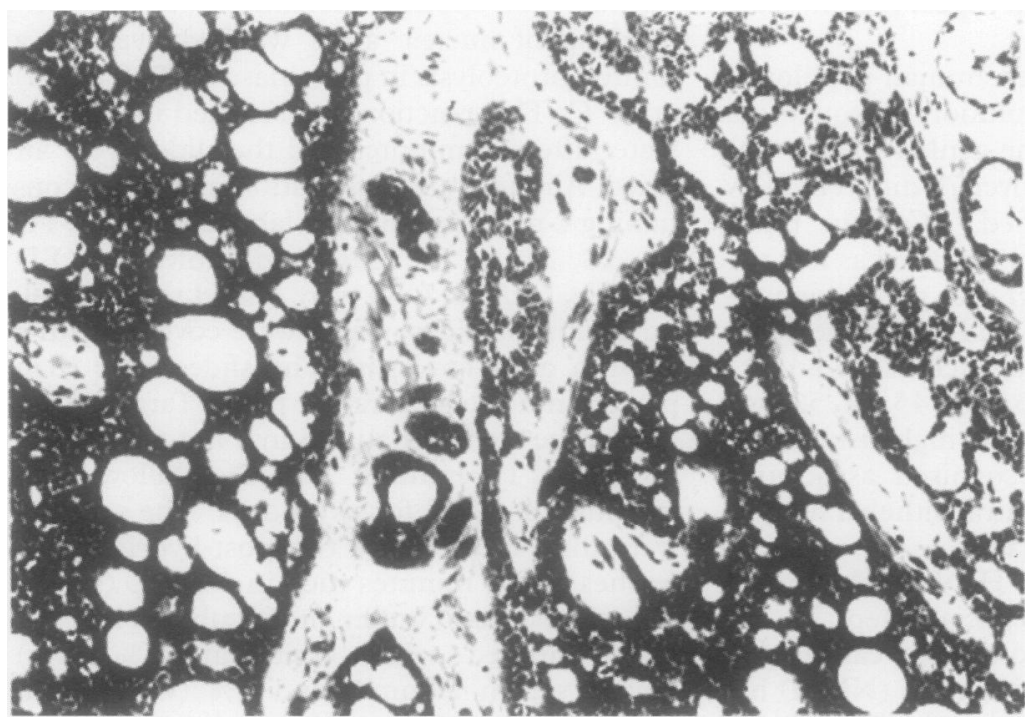

Figure 1 Photomicrograph of cervical adenoid cystic carcinoma showing characteristic cribriform architecture and basement membrane material. (Haematoxylin and eosin; original magnification $\times 100$.) cross-contamination of samples. The sections were dewaxed and rehydrated following the standard protocol, rinsed in sterile distilled water and allowed to dry. DNA was extracted from the samples using the Qiagen QIAamp tissue kit (Qiagen Ltd, UK). The samples were suspended in a lysis buffer containing proteinase $\mathrm{K}$ and incubated overnight at $55^{\circ} \mathrm{C}$. DNA was precipitated with ethanol in a spin column and finally eluted in water. A $10 \mu$ l aliquot of each DNA sample was amplified using a mixture of positive and negative strand primers to the E6 region. ${ }^{26}$ Each $50 \mu \mathrm{l}$ reaction contained $10 \mathrm{mM}$ Tris- $\mathrm{HCl}, 50 \mathrm{mM} \mathrm{KCl}, 4 \mathrm{mM}$ $\mathrm{MgCl}, 200 \mu \mathrm{M}$ DNTP, 2.5 units Taq polymer- ๊ ase (Boehringer Mannheim), and $0.1 \mu \mathrm{M}$ each of primers WD72, WD66 and WD154, and $0.4 \mu \mathrm{M}$ of WD76 and WD67. The PCR primer sequences are given in table 1 .

Parallel amplification of the $\beta$-globin gene (GH20 and PC04) was performed to deter- 0 mine the integrity of the DNA in each sample. $\vec{\circ}$

Conditions for HPV E6 and $\beta$-globin PCR assays, carried out on a Perkin Elmer thermo- of cycler, were as follows: four minutes at $94^{\circ} \mathrm{C}$ 윽 followed by 40 cycles of one minute at $95^{\circ} \mathrm{C}$, $\vec{O}$ one minute at $55^{\circ} \mathrm{C}$, one minute at $72^{\circ} \mathrm{C}$, and a five minute extension period at $72^{\circ} \mathrm{C}$.

Fifteen microlitres of the amplification product were analysed for the expected amplimers ( 240 base pairs (bp) for HPV and 268 bp for $\beta$-globin) on a $3 \%$ agarose gel, and stained with ethidium bromide. The molecular weight of the products was determined by comparison with DNA molecular weight marker V (pBR 322 DNA cleaved with Hae III) (Boehringer Mannheim).

Gels were viewed with an ultraviolet transilluminator and photographed on Polaroid film.

\section{Results}

The clinical profiles of the 11 cases of adenoid cystic carcinoma are documented in table 2 . The age of the patients was known in seven cases and ranged from 54 to 109 years. The mean age was 77 years, a figure similar to that reported in the literature. ${ }^{26}$ All nine patients in whom the race was known were black. Histologically, all 11 cases showed a variable combination of growth patterns, including rounded cribriform islands and nests (fig 1), as well as sheets, trabeculae and cords of cells. N Two cases showed predominantly solid growth, $\bar{O}$ a subtype which has been referred to as the 0

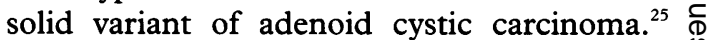
One case (case 3 ) showed grade III CIN of the overlying surface epithelium, arising from 0 which was an infiltrating squamous cell carci- $\stackrel{\vec{D}}{\mathbb{D}}$ noma (SCC). The superficially invasive o squamous carcinoma islands showed an abrupt $\triangle$ transition to classic adenoid cystic carcinoma. Another case (case 6) showed adenoid cystic of carcinoma arising directly from overlying CIN III. Case 4 showed microscopic foci of squamous differentiation.

NON-ISOTOPIC IN SITU HYBRIDISATION

Eight patients harboured HPV DNA (table 3). Of these, seven tumours contained HPV 16, whilst the remaining tumour was positive for 


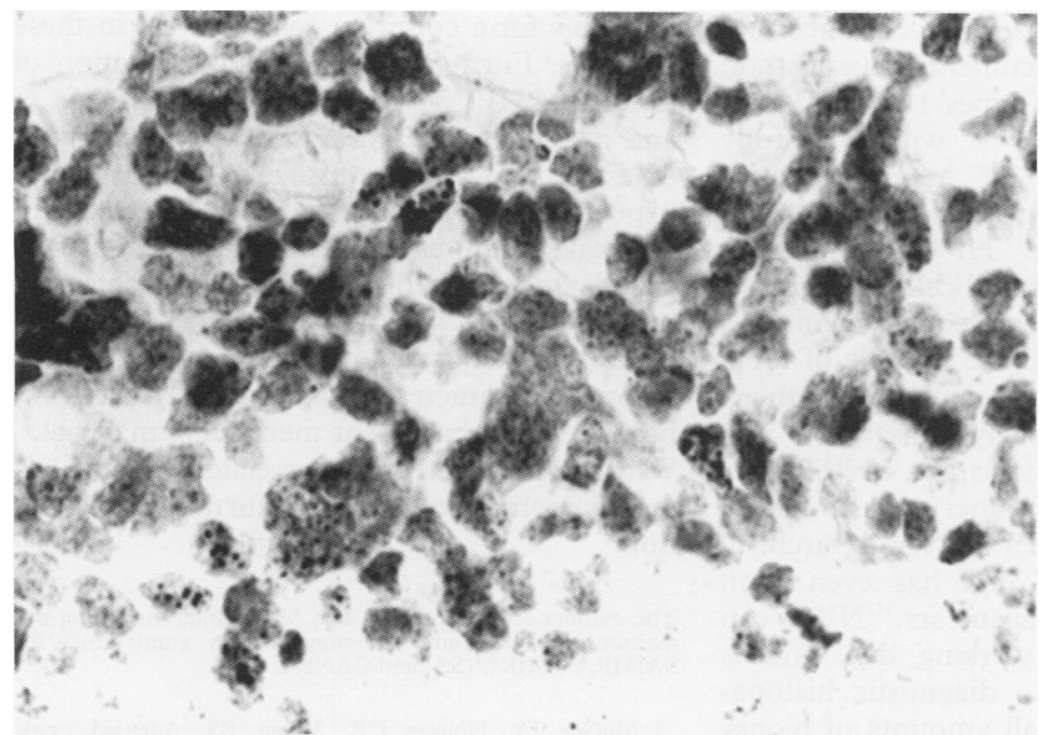

Figure 2 Cervical adenoid cystic carcinoma cells showing punctate (type 2) as well as combined punctate and diffuse (type 3) signals by NISH.

Table 3 Analysis of HPV in 11 cases of adenoid cystic carcinoma of the cervix by NISH and PCR

\begin{tabular}{lllll}
\hline Case number & $\begin{array}{c}H P V \\
\text { type }\end{array}$ & NISH & Signal type & PCR \\
\hline 1 & 16 & Negative & 2 & $\begin{array}{l}\text { Negative } \\
\text { Negative }\end{array}$ \\
2 & 16 & & $1,2,3$ & Negative \\
3 & 16 & & 2,3 & Positive \\
4 & 16 & & $2,2,3$ & Positive \\
5 & 16 & & $1,2,3$ & Positive \\
6 & 16 & Negitive \\
7 & & Negative & & Negative \\
8 & 31 & & 1,2 & Negative \\
9 & 16 & & 2 & Pegative \\
10 & & & Positive \\
11 & &
\end{tabular}

${ }^{\star}$ HPV types $6,11,18$, and 33 were not present in any of the specimens.

Signal type: type 1 = diffuse; type 2 = punctate; type 3 = combined punctate and diffuse.

HPV 31. The NISH signal pattern was analysed using the criteria established by Cooper et al. ${ }^{16} \quad 28$ All eight NISH positive tumours contained integrated HPV DNA, as can be seen by the presence of a type 2 (punctate) signal or a type 3 (combined punctate and diffuse) signal, or both (fig 2). Four of these cases also had scattered cells with a type 1 (diffuse) signal indicative of episomal HPV DNA. The positive NISH signals were generally encountered in small groups of cells randomly distributed within the tumour. None of the tumours contained more than one HPV type. In case 3 , the tumour with associated CIN III and SCC had HPV 16 positive (types 1,2 and 3) signals in the in situ neoplastic component, and numerous type 2 and type 3 signals in both the minor invasive SCC component and the adenoid cystic carcinoma. The single HPV 31 positive tumour (case 6) had a similar NISH signal pattern in its CIN III and invasive adenoid cystic carcinoma components.

Neither episomal nor integrated HPV 6, 11, 18 , or 33 was identified in any of the tumours. POLYMERASE CHAIN REACTION

Amplimers of the HPV E6 gene $(240 \mathrm{bp})$ were present in five of the eight NISH positive tumours (fig 3). The three PCR negative, NISH positive cases included two HPV 16 positive tumours and the single HPV 31 positive case (table 3 ). The three NISH negative adenoid cystic carcinomas also failed to demonstrate HPV DNA by PCR.

\section{Discussion}

Adenoid cystic carcinoma of the cervix is an uncommon neoplasm with a worse prognosis than conventional squamous cell carcinoma. ${ }^{25}$ To date, more than 140 cases have been reported. The vast majority occur in black postmenopausal women, with an average age of 72 years. ${ }^{23} 24$ The cases in the present series reflect a similar clinical profile.

To our knowledge, this is the first study to investigate the role of HPV in these rare cervical carcinomas. Integrated HPV $16,18,33$, and 35 have been demonstrated previously in $\mathrm{CIN},{ }^{15}$ and HPV types 16,18 and 33 have been

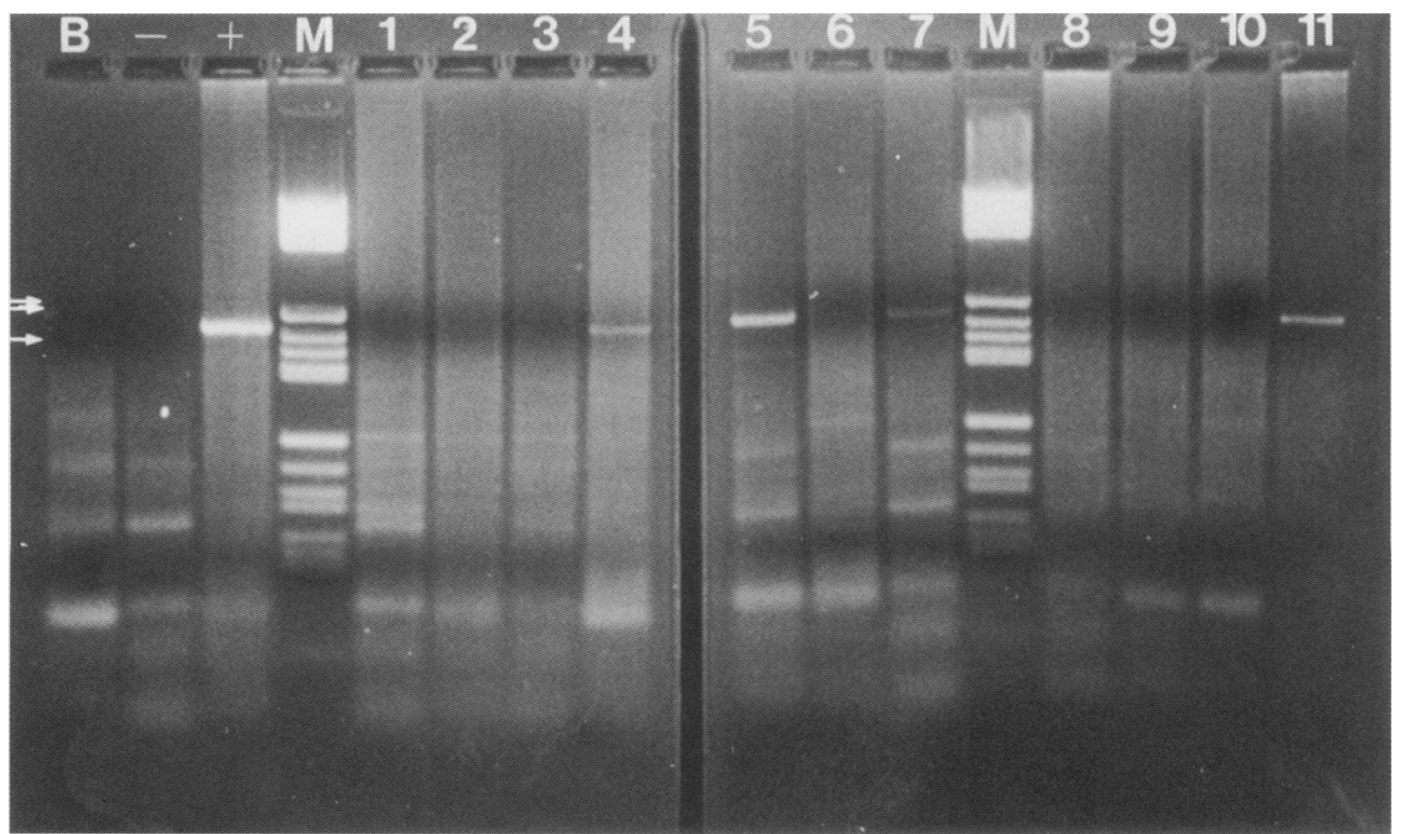

Figure 3 PCR confirmation of HPV DNA in five of the 11 cases of adenoid cystic carcinoma. Case 6 shows a weak band $(240 \mathrm{bp}) . \rightarrow=234 \mathrm{bp} ; \rightrightarrows=267 \mathrm{bp} ; B=$ blank; $-=$ negative control $;+=$ positive control; $M=$ molecular weight marker. 
implicated in cervical squamous cell cancer. ${ }^{16} 18$ There is also a well documented association between integrated HPV types 16 and 18 and cervical adenocarcinoma, ${ }^{17}{ }^{20}$ with one study also implicating HPV $33 .{ }^{29}$ Adenosquamous carcinoma may be associated with HPV 16, $18^{18}$ or even 31 infection. ${ }^{19} \mathrm{HPV} 18$ is strongly associated with cervical small cell carcinoma. ${ }^{18}$

In recent years, several molecular techniques have been used to investigate the role of HPV in cervical cancers. These include Southern blot analysis, ${ }^{13} 20$ dot blot hybridisation ${ }^{29}$ and fluorescence in situ hybridisation. ${ }^{18} \mathrm{NISH}$ has, however, emerged as a superior tool in the identification of the HPV DNA in archival biopsy material, ${ }^{15-1728}{ }^{30}$ and has even been applied to routine cervical smears. ${ }^{31} \mathrm{NISH}$ can be completed in one working day, and is particularly applicable to diagnostic histopathology in that only small amounts of biopsy material are required, morphology is preserved and specific signal patterns are generated. ${ }^{14}$

Using this technique we have demonstrated a punctate NISH signal pattern, thus confirming the integration of high risk HPV DNA, in particular HPV 16, in cervical adenoid cystic carcinoma. Integration of viral DNA into the host cell genome is recognised as a crucial event in cervical carcinogenesis. The integration of HPV DNA into the host genome is responsible for disruption of the E2 gene, ${ }^{13}{ }^{32}$ leading to a loss of its transactivating repressive effects on the E6 and E7 gene couple. ${ }^{14}$ The result is an overproduction of E6 and E7 viral oncoproteins which have the ability to bind host $\mathrm{p} 53^{33}$ and retinoblastoma gene products, respectively. ${ }^{35}$ As a consequence, functional regulation of host cell growth is lost, giving rise to an abnormal proliferation, ${ }^{36}$ contributing to the neoplastic growth of cervical epithelia.

An interesting observation in the present series was the increased detection of HPV DNA with the NISH technique compared with PCR. Three discordant NISH positive/PCR negative cases were identified. The NISH system has been shown to detect as few as 2.5-20 viral copies per cell. ${ }^{28}{ }^{30}$ In contrast, the detection of HPV in archival material using PCR requires a minimum of 400 copies per sample. ${ }^{37}$ These observations may offer a plausible explanation for the detection of HPV by PCR in only five of the eight adenoid cystic carcinomas shown to harbour integrated HPV DNA by NISH. Alternatively, tissue fixation or PCR inhibitors in paraffin wax embedded material may account for this discrepancy.

Although the present study has definitively demonstrated integrated high risk HPV genomic material in adenoid cystic carcinoma, the reasons for the rarity of this neoplasm and its almost exclusive occurrence in postmenopausal black women remain obscure. A possible explanation for this is that a long period of latent infection is required prior to integration into the host genome. Alternatively, an as yet unidentified co-factor may be required in the evolution of this tumour type.

The two cases in the present study in which co-existing squamous cell carcinoma with adenoid cystic carcinoma was demonstrated, mitigates for a common cell of origin in these tumours. Furthermore, the demonstration of integrated HPV 16 or 31 in both the CIN/SCC and adenoid cystic carcinoma components in cases 3 and 6, respectively, supports this hypothesis. In addition, HPV infection of cervical squamous epithelium has been closely correlated with keratin production, ${ }^{38}$ accounting for the HPV positive keratinising squamous cell carcinoma. In contrast, adenoid cystic car- $\overrightarrow{\overrightarrow{0}}$ cinoma is characterised by strikingly excessive $\bar{O}$ production of basement membrane material. ${ }^{25}$ Whether HPV infection correlates with the latter phenomenon warrants further investigation.

The authors are indebted to Mrs M Miranda for typing this manuscript. The study was supported by grants from the SAIMR, the MRC (SA) and CANSA

1 McGee JA, Flowers CE, Tatum BS Adenoid cystic carcinoma of the cervix. Obstet Gynecol 1965;26:356.

2 Spiro RH, Huvos Ag, Strong EW. Adenoid cystic carcinoma of salivary origin: A clinico-pathological study of 242 cases. Am $\mathcal{F}$ Surg 1974;128:512-20.

3 Shimosato Y, Kodama T. Low grade malignant and benign tumours. In: McDowell EM, ed. Lung carcinomas. Edinburgh: Churchill Livingstone, 1987:310-29.

4 Epstein JI, Sears DL, Tucker RS, Eagan JW Jr. Carcinoma of the esophagus with adenoid cystic differentiation. Cancer 1984;53:1131-6.

5 Peters GN, Wolff $M$. Adenoid cystic carcinoma of the breast. Report of 11 new cases: Review of the literature and discussion of the biological behaviour. Cancer 1983;52: discuss.

6 Heffner DK, Hyams VJ, Hauck KW, Lingeman C. Low-Grade adenocarcinoma of the nasal cavity and Low-Grade adenocarcinoma of the nas
paranasal sinuses. Cancer 1982;50:312-22.

7 Michaels L. The ear. In: Sternberg SS, ed. Diagnostic surgical pathology. Vol 1.2nd edn. New York: Raven Press, 1994: 926

8 Frankel K, Craig JR. Adenoid cystic carcinoma of the prostate. Am f Clin Pathol 1974; 62:639-45.

9 De Villiers E-M. Heterogeneity of the human papillomavirus group. 7 Virol 1989;63:4898-903.

10 Zur Hausen H. Papilloma viruses in ano-genital cancer as a model to understand the role of viruses in human cancer. Cancer Res 1989;49:4677-81.

11 Chang F. Role of papillomaviruses. F Clin Pathol 1990;43: 269-76.

12 McDougall JK. Human papillomavirus immortalising and transformation. Papilloma Virus Report 1990;1:1-4

13 Choo K-B, Pan C-C, Han S-H. Integration of human papillomavirus type 16 into cellular DNA of cervical carcinoma: Preferential deletion of the E2 gene and invariable retention of the long control region and the E6/E7 open reading frames. Virology 1987;161:259-61.

14 Cooper $\mathrm{K}$. The role of human papillomavirus in cervical cancer [editorial]. S Afr Med $\mathcal{f}$ 1995;85:841-2.

15 Cooper K, Herrington CS, Graham AK, Evans MF, McGee JO'D. In situ human papillomavirus (HPV) genotyping of cervical intraepithelial neoplasia in South African and British patients: Evidence for putative HPV integration in vivo. f Clin Pathol 1991;44:400-5.

16 Cooper K, Herrington CS, Graham AK, Evans MF, McGee $\mathrm{N}$ JO'D. In situ evidence for HPV $16,18,33$ integration in 0 cervical squamous cell cancer in Britain and South Africa. $N$ f Clin Pathol 1991;44:406-9.

17 Cooper K, Herrington CS, Lo ES-F, Evans MF, McGee N JO'D. Integration of human papillomavirus types 17 and $18 \sigma$ in cervical adenocarinom 7 Clin Path $1992: 45: 382-4$.

18 Stoler MH, Rhodes CR, Whitbeck A, Wolinsky SM, Chow 0 LT, Broker TR. Human papillomavirus types 16 and 18 gene expression in cervical neoplasias. Hum Pathol \& 1992;23:117-28.

19 Gordon AN, Bornstein J, Kaufman RH, Estrada RG, T Adams E, Adler-Storthz K. Human papillomavirus associated with adenocarcinoma and adenosquamous carcinoma of the cervix: Analysis by in situ hybridization. Gynecol Oncol 1989;35:345-8.

20 Wilczynski SP, Walker J, Liao S-Y, Bergen S, Berman M Adenocarcinoma of the cervix associated with human pap- $\sigma$ illomavirus. Cancer 1988;62:1331-6.

21 Musa AG, Hughes RR, Coleman SA. Adenoid cystic carcinoma of the cervix: A report of 17 cases. Gynecol Oncol noma of the cer

22 Young RH, Scully RE. Invasive adenocarcinoma and related tumours of the uterine cervix. Semin Diagn Pathol 1990;7: tumours

23 Young RH, Clement PB, Scully RE. Premalignant and malignant glandular lesions of the uterine cervix. In: Clement PB, Young RH, eds. Tumors and tumor-like lesions of the uterine corpus and cervix. New York: Churchill Livingstone, 1993:124-36.

24 Kurman RJ, Norris HJ, Wilkinson EJ. Tumours of the cervix. In: Rosai J, Sobin LH eds. Atlas of tumour pathology. 
Fascicle 4. 3rd series. Tumours of the cervix, vagina and vulva. Washington, DC: Armed Forces Institute of Pathology, 1992:100-1.

25 Albores-Saavaedra J, Manivel C, Mora A, Vuitch F, Milchgrub $S$, Gould $E$. The solid variant of adenoid cystic carcinoma of the cervix. Int $f$ Gymecol Pathol 1992;11:2-10.

26 Bauer HM, Greer CE, Manos MM. Determination of genital papillomavirus infection by consensus polymerase chain reaction amplification In: Herrington CS, McGee JO'D eds. Diagnostic molecular pathology-A practical approach. Vol II. Oxford: Oxford University Press, 1991:131-51.

27 Ferry JA, Scully RE. "Adenoid cystic" carcinoma and adenoid basal carcinoma of the uterine cervix: A study of 28 cases. Am $\mathcal{F}$ Surg Pathol 1988;12:134-44.

28 Cooper K, Herrington CS, Stickland JE, Evans MF, McGee JO'D . Episomal and integrated human papillomavirus in cervical neoplasia shown by non-isotopic in situ hybridisation. F Clin Pathol 1991;44:990-6. tion. 7 Clin Pathol 1991;44:990-6.

Duggan MA, Benoit JL, Mc Gregor SE, Nation JG, Inoue M, Stuart GC. The human papillomavirus status of 114 endocervical adenocarcinoma cases by dot blot hybridization. Hum Pathol 1993;24:121-5.

30 Cooper $\mathrm{K}$. Human papillomavirus and endocervical adenocarcinoma [letter]. Hum Pathol 1994;25:216-17.

31 Herrington CS, De Angelis M, Evans MF, Troncone G, $M c G e e$ J'D. Detection of high risk human papillomavirus in routine cervical smears: Strategy for screening. $\mathcal{F}$ Clin Pathol 1992;45:385-90.

32 Schwarz E, Freese UK, Gissmann L, Mayer W, Roggenbuck B, Stremlau A, et al. Structure and transcription of human papillomavirus sequences in cervical carcinoma cells. papillomavirus sequences

33 Scheffner M, Werness BA, Huibregtse JM, Levine AJ, Howley PM. The E6 oncoprotein encoded by human papillomavirus types 16 and 18 promotes the degradation of p53. Cell 1990;63:1129-36.

34 Werness BA, Levine AJ, Howley PM. Association of human papillomavirus types 16 and $18 \mathrm{E} 6$ proteins with p53. Science 1990;148:76-9.

35 Dyson N, Howley PM, Munger K, Harlow E. The human papillomavirus-16 E7 oncoprotein is able to bind to the retinoblastoma gene product. Science 1989;243:934-7.

36 Vousden $\mathrm{KH}$, Wrede D, Crook T. Human papillomavirus oncoprotein function: Releasing the brakes on cell growth control. Papilloma Virus Report 1991;2:1-3.

37 Shibata D, Fu YS Gupta JW, Shah JV, Arnheim N, Martin WJ. Detection of human papillomavirus in normal and dysplastic tissue by the polymerase chain reaction. $L a b$ Invest 1988;59:555-9.

38 Broker TR, Botchan M. Papillomaviruses: retrospectives and prospectives. Cancer Cells 1986;4:17-36. 